\title{
One Analogy Can Hide Another: Physics and Biology in Alchian's "Economic Natural Selection"
}

\author{
Clément Levallois
}

\begin{tabular}{|l|l|}
\hline \multicolumn{2}{|l|}{ ERIM REPORT SERIES RESEARCH IN MANAGEMENT } \\
\hline ERIM Report Series reference number & ERS-2008-083-MKT \\
\hline Publication & December 2008 \\
\hline Number of pages & 19 \\
\hline Persistent paper URL & http://hdl.handle.net/1765/14278 \\
\hline Email address corresponding author & clevallois@rsm.nl \\
\hline Address & Erasmus Research Institute of Management (ERIM) \\
& RSM Erasmus University / Erasmus School of Economics \\
& Erasmus Universiteit Rotterdam \\
& P.O.Box 1738 \\
& 3000 DR Rotterdam, The Netherlands \\
& Phone: + 31 10 408 1182 \\
& Fax: + 31 10 408 9640 \\
& Email: info@erim.eur.nl \\
& Internet: $\quad$ www.erim.eur.nl \\
\hline
\end{tabular}

Bibliographic data and classifications of all the ERIM reports are also available on the ERIM website: www.erim.eur.nl 


\section{ERASMUS RESEARCH INSTITUTE OF MANAGEMENT}

\section{REPORT SERIES}

\section{RESEARCH IN MANAGEMENT}

\begin{tabular}{|l|l|}
\hline ABSTRACT AND KEYWORDS \\
\hline Abstract & $\begin{array}{l}\text { Today, Alchian's "Uncertainty, evolution and economic theory" (1950) is hailed by evolutionary } \\
\text { economists as a most important piece, which resumed an evolutionary brand of theorizing in } \\
\text { economics after the eclipse of the interwar period. On the other hand, Alchian's article is also } \\
\text { cherished by standard economists who consider it to be a powerful defense of the maximization } \\
\text { principle in the theory of the firm. Our examination of the early intellectual life of Alchian shows } \\
\text { that it was his involvement in military systems analysis at the Rand Corporation that led him to } \\
\text { reckon that uncertainty was a fundamental obstacle to marginal analysis. We then demonstrate } \\
\text { that Alchian's economic natural selection is a statistical argument which, if phrased in biological } \\
\text { parlance, owes its logic to statistical mechanics. This invites to reconsider the strong opposition } \\
\text { usually made between evolutionist and mechanist modes of thinking. }\end{array}$ \\
\hline Free Keywords & $\begin{array}{l}\text { evolutionary economics, statistical mechanics, Rand Corporation, Ronald A. Fisher, } \\
\text { Armen A. Alchian, theory of the firm }\end{array}$ \\
\hline Availability & $\begin{array}{l}\text { The ERIM Report Series is distributed through the following platforms: } \\
\text { Academic Repository at Erasmus University (DEAR), DEAR ERIM Series Portal } \\
\text { Social Science Research Network (SSRN), SSRN ERIM Series Webpage } \\
\text { Research Papers in Economics (REPEC), } \underline{\text { REPEC ERIM Series Webpage }}\end{array}$ \\
\hline Classifications & $\begin{array}{l}\text { The electronic versions of the papers in the ERIM report Series contain bibliographic metadata } \\
\text { by the following classification systems: } \\
\text { Library of Congress Classification, (LCC) LCC Webpage } \\
\text { Journal of Economic Literature, (JEL), JEL Webpage } \\
\text { ACM Computing Classification System CCS Webpage } \\
\text { Inspec Classification scheme (ICS), ICS Webpage }\end{array}$ \\
\hline
\end{tabular}




\title{
One Analogy Can Hide Another: Physics and Biology in Alchian's "Economic Natural Selection"
}

\author{
Clément Levallois
}

Historiography has placed Armen Alchian’s “Uncertainty, Evolution, and Economic Theory" (1950) at the crossroads of two methodological episodes: the epilogue of the marginalist controversy and the rebirth of evolutionary theories. For some, Alchian's was one of the last contributions to the marginal analysis controversy, which started with Robert Hall and Charles Hitch's (1939) argument that businessmen do not determine price according to the prescription of the marginal analysis, but use instead a rule of thumb based on the full costs of production. This result triggered a long series of counterarguments and rejoinders, in particular by Richard Lester (1946) and Fritz Machlup (1946). Alchian's argument in the 1950 paper presents itself as a defense of marginal analysis. Alchian agreed that

Correspondence may be addressed to Clément Levallois, Centre for Neuroeconomics, ERIM, Erasmus University Rotterdam, P.O. Box 1738, 3000 DR Rotterdam, The Netherlands; e-mail: clevallois@rsm.nl. This article is an adaptation of a chapter of my doctoral dissertation on economics and biology in the postwar United States, defended in February 2008 at Université Lumière Lyon 2. I am grateful to EconomiX-Cachan; Triangle, UMR 5206 CNRS; the Centre for Philosophy of Natural and Social Science at the London School of Economics; and the Department of Economics at City University London for support during this research. Agence Nationale de la Recherche (ANR) also provided financial support. I gratefully acknowledge helpful comments and suggestions from Philippe Fontaine, Jean-Pierre Potier, Roger Backhouse, Andy Denis, Judy Klein, and from the participants in the Young Scholar session of the European Society for the History of Economic Thought meetings, Strasbourg, July 2007. I thank Béatrice Cherrier and Philip Mirowski for providing me with a copy of the Alchian-Friedman correspondence, and Alice E. Obrecht for her kind assistance in the transcription of Alchian's interview. All remaining errors are mine.

History of Political Economy 41:1 DOI 10.1215/00182702-2008-041

Copyright 2009 by Duke University Press 
maximum profit is an impossible objective to pursue given the fundamental uncertainty of future production and market conditions. Still, some firms would eventually (by sheer luck or otherwise) hit optimal pricing policies with regard to the observed realized market conditions. Provided that competition was intense enough, these firms would therefore get maximum realized profits and prosper, while less performing firms would be driven out of business. Whatever the actual behavior of entrepreneurs emerging from empirical surveys, economists equipped with marginal analysis could still proceed "as if" firms were maximizing entities. ${ }^{1}$

Others were concerned with the biological analogy at work in Alchian's article. Alchian $(1950,214)$ argued that the relative performance of firms, measured by their ex post profits, is comparable to the differential survival of organisms, determined by the degree of adaptation to their environment, as professed by the theory of natural selection:

Consider, first, the simplest type of biological evolution. Plants "grow" to the sunny side of buildings not because they "want to" in awareness of the fact that optimum or better conditions prevail there but rather because the leaves that happen to have more sunlight grow faster and their feeding systems become stronger. . . . There may have been no motivated individual adapting but, instead, only environmental adopting.

"The economic counterparts of genetic heredity, mutations, and natural selection are imitation, innovation, and positive profits" (220), he concluded.

On Alchian's own admission, it was the first of these two views that informed the writing of his article. In a comment on an article by Edith Penrose, who criticized his use of a biological analogy in a social context, Alchian $(1953,601)$ replied that "the theory I presented stands independently of the biological analogy," and explained that "readers of an earlier draft, containing no references to the biological similarity, urged the analogy be included as helpful to an understanding of the basic

1. The methodological dimension of the controversy was surveyed by Frederic Lee (1984), who provides also some historical context, but he stops short of including Alchian's article. Philippe Mongin $(1986,1992)$ argued that the controversy leads to Milton Friedman's methodological thesis that theoretical assumptions need not be realistic, which Friedman (1953) indeed spelled out in explicit opposition to the critics of marginal analysis. The biological analogy in Alchian's article and the subsequent exchange with Stephen Enke $(1951,1953)$ and Edith Penrose $(1952,1953)$ are discussed in the following: Winter [1964] 1988; Hirshleifer 1977; Kirat 1991; Hodgson 1993, 198-99; Hodgson 1994; Vromen 1995; Lagueux 1998; Solal 1999; Hodgson 2005; and Levallois 2008. 
approach."2 This may well have been an easy way out of Penrose's criticisms, since Alchian added that "criticisms of the latter [the biological analogy] are irrelevant to the theory." Yet, at a conference on evolutionary theories in economics and law, to which Alchian was invited as one of the founding fathers, he stated:

[Sidney] Winter: I saw the phrase-the Alchian paradigm on the outline [of the conference]. Alchian: Can I just say something? It's very embarrassing, you write an article in response to two misplaced articles, one by a fellow named Lester and one by a guy named Machlup. Lester was arguing that businessmen do not think in terms of Marshall's cost calculations and it therefore can't be right; and Machlup says oh, yes they do and therefore it is right. Both of them irrelevant positions and so you simply apply the well-known evolutionary theory, put it on a paper, and it becomes a classic. (Alchian 1982, 149)

It is the basic contention of the present article that this is not the end of the story. Alchian's handling of the marginal controversy was but one instance of his attempts to reconcile the existing analytical framework of economics with relevant aspects of economic reality, through the use of statistical arguments. Once this has been recognized, it is realized that Alchian's solution to the controversy was chiefly a statistical one, and secondarily an evolutionary one. The main support to our claim is that Alchian used not one but two overlapping analogies in his paper, one of which concerned statistical mechanics. The overlap, it is argued, explains why Alchian's economic natural selection lent itself so easily both to the advocates of maximization and to evolutionary economists.

We will focus on Alchian's education in statistics and his early career, pointing to the permeation of contemporary statistics with biological meaning. During the following years Alchian spent at the RAND Corporation, the early studies in systems analysis (and their failure) convinced him that uncertainty was a central challenge, threatening the core assumptions of marginal analysis. We will then make use of this background to

2. On the direct source of this analogy, Alchian explains that it was during a classroom exposition of Lester's and Machlup's articles that he came up with the biological analogy. Then, "words of my comments passed to my colleague Professor Stephen Enke, as sensible and practical an economist as you would ever want to know. He remarked that the comments would make a publishable article. I scoffed that it was all too obvious and trivial, and appropriate only for class lecture, not as a publishable article. He nevertheless urged me to write it at least for future classroom handouts" (Alchian [1996] 2006, xxiii). 
provide a new understanding of Alchian's “Uncertainty, Evolution, and Economic Theory." We argue that its biological analogy was itself molded after a mechanical analogy. The economics of the firm Alchian was investigating in the paper, the natural selection he was referring to, and the underlying mechanical analogy, all were statistical answers to the challenge presented by uncertainty-precisely the main interest of Alchian while he was at RAND.

\section{Alchian and Fisherian Statistics}

Alchian was born in 1914 in Fresno, California. He was from a modest background, and when he was awarded a scholarship to study at Stanford University in 1932, without additional financial support, he had to decline and go to Fresno College instead. He finally entered Stanford in 1934, where he received his BA in economics in 1936. In 1938, he took a course in statistics with economist and statistician W. Allen Wallis. Alchian (2000) recalls: "[Wallis was one of the] big heroes of my life. . . . he gave us the modern new statistics. A real eye opener. It was a great probability theory. He gave us R. A. Fisher's biological methods, [which] were hard as hell to read." He also remembers vividly one particular problem:

And the famous lady tasting tea. . . . The lady claimed she could tell when you gave her a cup of tea, whether you put the cream in first, or whether you put the sugar in first. And your problem was to test her ability to do that. How would you design the experiment? That was [Wallis's] first [problem], and it was a good problem. Design an experiment, test a new hypothesis and all that. ... that was the new statistics. ${ }^{3}$

The "new statistics" of Ronald A. Fisher had been introduced in the United States by Harold Hotelling, who had spent the second half of 1929 working with Fisher at the Rothamsted Experimental Station and kept close contact with him afterward. Wallis had been a student of Hotelling at Columbia in 1935-36, and as Alchian's recollection testifies, Wallis had well absorbed the Fisherian approach to statistics (Oklin 1991; Smith 1978). Alchian's mention of the "biological methods" points to the context in which statistics was developed at that time. Whereas in the United

3. This problem had its origin at a tea party that took place just a few years before, in Cambridge, England, when a lady actually made this claim. Among the guests, it was Ronald Fisher who proposed to devise an experiment to test her claim (Salsburg 2001). 
States, professional interest in statistics was overwhelmingly related to social issues, as shown by the membership of the American Statistical Association (Rice and Green 1929; Funkhouser 1941), in Britain statistics had a close connection to the treatment of biological issues. Biometrika was still the leading journal of the field, and Fisher, the leading statistician of his time, was also one of the founders of the "Neo Darwinian synthesis." His Genetical Theory of Natural Selection (1930) presented a statistical model of evolution along the principles of Mendelian genetics. Finally, in relation to his eugenic views, Fisher had a continuing interest in the statistical investigation of heredity.

Inevitably, the importation of Fisherian statistics into social science bore some mark of this biological context. Fisher's Statistical Methods for Research Workers ([1925] 1932), which went through fourteen Englishlanguage editions and was meant originally as an introduction especially for biologists, found an audience extending to the wider scientific community (Salsburg 2001, 38). The editor's preface pointed out that, indeed, "conspicuous progress is now being seen in the field of general physiology, of experimental biology, and in the application of biological principles to economic problems" (Fisher [1925] 1932, v). This meant that economists such as Alchian, who were the first generation learning statistics through Fisher's books, probably read his Statistical Methods for Research Workers, ${ }^{4}$ in which the Poisson series was illustrated by an application to "motile organisms," or studied the binomial distribution through a discussion of its fit to some data on sex ratios. ${ }^{5}$

Alchian was inevitably confronted with biology as the primary field in which modern statistics had been developed. It infused him with a view of Darwinism not concerned with the particularities of the economy of

4. This was actually the case for Alchian, who provides further indications of his education in biology with a revealing slip when he mentions the title of Fisher's book: "I was fortunate to have had a father who thrust my nose into Darwin's Origins when I was in high school. Then, in college, I had a course in biology which was all Darwin and evolution. Finally, at the graduate level, I was fortunate to have worked with Professor Wallis, who introduced me to R. A. Fisher's Statistical Methods for Biological Research [sic]" Alchian ([1996] 2006, xxiii-xxiv).

5. It is likely that Alchian also studied Fisher's other important textbook, The Design of Experiments (1935). Indeed, the second chapter of this book illustrated the principles of experimentation through a "psycho-physical experiment," consisting in "[a] lady declar[ing] that by tasting a cup of tea made with milk she [could] discriminate whether milk or the tea infusion was first added to the cup" (Fisher 1935, 13). The third chapter (possibly the second lesson Wallis taught to his students) introduced Student's $t$-test and was illustrated by data drawn from Charles Darwin's inquiry on the growth rates of inbred and cross-bred plants. 
nature, comprising the details of the physical settings and the actual interactions between species describing an ecosystem. Rather, Darwinism as perceived through Fisher was dealing with populations of individuals characterized by demographical parameters, statistically defined (basically, birth and death rates, the Malthusian parameter), governing their path toward expansion or extinction. It was an illustration of how a statistical approach could reconcile the complex agency of evolved species with the dynamics of inherently stochastic moves at the genetic level. In a similar way, Alchian's article claimed to explain the orderly agency of an industry composed of optimizing firms, while giving full credence to the erratic behavior of firms at the individual level-by means of a statistical argument.

On his own admission, Alchian's economics dissertation was not stimulating, and he found much more interest in the statistical work he accomplished when the war broke out. Alchian was engaged at Fort Worth for the Army Air Force. There, he applied straightforwardly what he had learned from Wallis, devising tests and procedures for the selection and placement of cadets in airplane crews. Relieved from duty in 1946 and ranking captain, he found a position as an associate professor at UCLA, a few miles from Santa Monica, where RAND was founded the same year (Hounshell 2000, 296 n. 4). ${ }^{6}$

\section{First Challenges at RAND}

As the operations research groups built up during World War II were progressively disbanded, scientists resumed their civil occupations. But, with the transition to the Cold War being so abrupt, some regretted that so successful an experience as operations research could not be prolonged in some form. Project RAND of the U.S. Air Force (formerly the Army Air Force) was then created in May 1946 precisely to provide such a place for civil scientists to work on a permanent basis on military matters. Project RAND was transformed into an independent organization in 1948 under the name of RAND Corporation, its financing coming from foundations such as Ford and from contracts with governmental institutions. RAND remained dedicated for a long time to studies in military airpower

6. "Alchian has written four chapters on the methods of statistical analysis employed in the AAF Aviation Psychology Program that are notable for their presentation of up-to-date concepts in surprisingly compact and straightforward fashion" (Davis 1948, 560). 
funded chiefly by the air force; it diversified its activities toward civil spatial research and public policies in the late 1950s. ${ }^{7}$

Well known in both military and academic circles, Wallis became one of the major consultants to RAND. When asked to gather scientists who could become consultants for RAND, he put forward Alchian as a suitable candidate. His former student was well trained in statistics, he was an officer in the air force, and lived nearby. At a conference held on 14-19 September 1947 by RAND to recruit social scientists, Alchian was one of the very few economists present. Hitch was another.

Hitch became the director of the economic division at RAND and Alchian the "first economist regularly engaged in research at The RAND Corporation" (Enke 1967, 74). He would serve as a consultant for two years, soon spending each afternoon and every Saturday at RAND. He would become a formal employee from 1949 to 1960, then again a consultant until $1964 .^{8}$

Alchian's first study at RAND was on learning curves in the aeronautic industry. He studied twenty-two types of airplanes (fighters and bombers) designed and produced during World War II. Learning curves, a phenomenon first characterized by Theodore Wright, predict that the amount of labor needed to produce the $n$th plane will be less than the amount of labor needed to produce the $n$th -1 unit. Alchian (2000) explained that the setting of the problem, in a practical way rather than in full abstraction, was determinant, because "in looking at a real problem, and trying to get a sensible answer, I have begun to realize that we had to understand it more fully":

In RAND, we began to look at the cost of producing different kinds of engines and parts. I started to work on the measurement of costs,

7. David Jardini's (1996) PhD dissertation is the best source available on RAND's history up to the seventies. See also Kaplan 1983, Leonard 1991, and Mirowski 1999, 2002. Kenneth Boulding $(1962,332)$ ironically noted: "The RAND Corporation is financed mainly by the United States Air Force, so that its studies must be accepted with the same kind of reserve that, shall we say, we might greet a study of the Reformation by Jesuits based on unpublished and secret documents of the Vatican."

8. The biographical information above is drawn from Alchian's personal file at RAND, cited by David Hounshell (2000). However, Alchian (2000) himself states that he "was a consultant all the time at RAND, never a staff member in the fullest sense." Given the publication policy of RAND, which keeps some reports classified (even their mere existence might be unreported to the public), our account is clearly incomplete. We are aware of Alchian's (1952) work on capital replacement policy at RAND, but we will not expand on it, for it does not modify our main argument though it brings further support to it. 
because they were costing airplanes. I'd go look at the literature, and I could not quite understand what they were talking about. . . I l looked at the engineering literature on costs, and we were getting results . . contrary to economic principles. They had falling marginal costs-they literally called them falling marginal costs. Now, any economist knows that marginal costs always are rising; they don't fall! But here these engineers ... Not only were they falling, they were falling at $20 \%$ every time you doubled the output! [It is] called the $80 \%$ curve. . . . [I said to Charlie Hitch] "Look at these data! Look at what we do!" He said, "That's interesting. Well, something is wrong."

With his article written with Hall in 1939, Hitch had some experience of data not fitting classic assumptions in economics. Alchian's own solution was not to dismiss the assumption, but to restate it. He pointed out that variations in output had two distinct sources: the volume of output could increase due to an increased rate of production or due to a longer production period. In the former case, one observed rising marginal costs (possibly due to physical nonlinearities in the production process), whereas in the latter case one observed falling marginal costs (due to a learning process), which corresponds to the conundrum of the " $80 \%$ curve" Alchian encountered in the engineering literature. ${ }^{9}$

Such a result was solid, because it solved the apparently inexplicable discrepancy between economic theory and hard-nosed facts. The latter were fully acknowledged and even given a better understanding, while the classic assumption in economics was restated in a new form, plainly coherent with the observed reality. One should think that this would be precisely the kind of result that his article on economic natural selection would achieve: to provide an analytical defense of a major assumption of marginal analysis against the challenge posed by empirical studies on entrepreneurial behavior, with contradicting observations fully acknowledged rather than explained away.

Still on learning curves in airframe production, Alchian's research highlighted another problem arising from the confrontation between

9. In the published version, Alchian suppressed the Cold War context of the problem and deleted the references to the planes, illustrating his reasoning by "automobile production and printing costs" instead. The paper was published in a volume celebrating one of his former teachers at Stanford (Alchian 1977), with an acknowledgment to "William Meckling of the RAND Corporation." The "learning curve," also called the "experience curve" or "progress curve," was popularized in the strategic literature in the late 1960s by the Boston Consulting Group. 
economic models and reality, leading him to an important conclusion about the role of uncertainty in economic theory. Learning curves were used by contractors to predict the production cost of airplanes, with equations typically taking the following form:

$$
\log _{10} m=a+b \log _{10} N,
$$

with $m$, the direct labor per pound necessitated for the production of the $N$ th plane.

Alchian put this relation to the test. His conclusion stated that for a given production of 1,000 airplanes, estimated learning curves such as the above were affected by an average error of prediction of 25 percent (Alchian 1963, 679). This result did not lead him to question the robustness of the relation ("the results cast doubts on any of the alternatives being better fits than the usual progress curves"); instead, Alchian insisted on the fundamental uncertainty inherent in such an attempt to predict costs. There again, Alchian was getting close to Hitch and Hall's objection to the postulate of rational decision making..$^{10} \mathrm{He}$ noted that some basic assumptions were doomed to be falsified once the actual production process was unfolding. The analyst's role would be then to provide the decision maker with an estimate of the uncertainty of the prediction, before the decision was made. In any case, reliable decisions could not be made if alternative programs were not "disparate beyond the range of uncertainty of error of estimate of the predictive method" (692). Reached in 1949 , this conclusion acknowledged uncertainty as a major obstacle to rational choice. If the difference between any two outcomes were so small that no one had an objective basis upon which to distinguish one from another, then there was no hope to reach a "rational" decision. ${ }^{11}$ Alchian's article on economic natural selection, written during the same time, defined uncertainty in precisely those terms:

Under uncertainty, by definition, each action that may be chosen is identified with a distribution of potential outcomes, not with a unique

10. It is to be noted that the published version of the paper makes an acknowledgment "to Charles Hitch, who encouraged and aided the study" (Alchian 1963, 679).

11. On the date of the writing of this article, Alchian stated in the abstract to his 1963 paper the following: "In 1948, when seeking estimates of costs of alternative weapon systems, the potentially embarrassing error of relating costs to rate of output while ignoring another relevant variable, quantity of items produced, was made obvious by access to the airframe production data analyzed in this paper. By 1949 the present paper had been completed for the RAND Corporation, but reliance on 'military classified' data and sources prevented open publication at that time." 
outcome. Implicit in uncertainty is the consequence that these distributions of potential outcomes are overlapping. [Here, there is a footnote that reads, "Thus uncertainty is defined here to be the phenomenon that produces overlapping distributions of potential outcomes."]

... Suppose one has the higher "mean" but a larger spread, so that it might result in larger profits or losses, and the other has a smaller "mean" and a smaller spread. Which one is the maximum? This is a nonsensical question. (Alchian 1950, 212)

Alchian hastened to add, "To ask for the optimum distribution is not nonsense.” But as his involvement with RAND's systems analysis taught him, it still raised the question of according to which criterion a given distribution would be deemed optimal.

Systems analysis was the integrated method of investigation that would become the hallmark of RAND's expertise in the 1950s, synonymous with scientific rigor and cold-blooded objectivity. Entrusted by the successes of operations research in World War II, and the fast-paced development of promising techniques such as game theory, systems analysts at RAND were confident that a "science of war" was at hand. Uncertainty, both technological and political, was a serious threat to such hopes. In January 1950, a major RAND project in systems analysis, devising a global aerial bombing system of an intercontinental target, was presented to the air force. The study was impressive from an analytical perspective, but practically speaking a disaster. A major issue was the criteria used to compare alternative bombing systems:

The report employed three different choice criteria: ratio of system cost to damage inflicted, ratio of pounds of aircraft lost to damage inflicted, and number of aircrews lost per damage inflicted. Of these, the ratio of system cost to amount of damage was the criterion upon which the primary optimizations were based, largely since it was most easily calculated with a comfortable degree of certitude. However, Air Force critics of the ... study, virtually all of whom were former aircrew members, reviled RAND's apparent reduction of human life to a quantifiable factor that was given, at best, equal weighting with machinery. (Jardini 1996, 61)

The critics of this study entered into a more general discussion of the "criteria problem" in the RAND economics department. Alchian was directly involved in the search for a criterion that could serve as a uni- 
versal yardstick to evaluate alternative outcomes in systems analysis. ${ }^{12} \mathrm{He}$ had been made conscious of how much uncertainty affects the production and costs of airplanes, and this convinced him that more powerful maximization techniques were not the solution to the problem (Hounshell 2000, 260). This is precisely how he stated the maximization problem in his article on economic natural selection:

In the presence of uncertainty . . . there is no meaningful criterion for selecting the decision that will "maximize profits." The maximumprofit criterion is not meaningful as a basis for selecting the action which will, in fact, result in an outcome with higher profits than any other action would have. (Alchian 1950, 212)

As we know, Alchian's way out of this problem was to appeal to the survival argument, which assured that among a large population of firms, those with positive profits would outcompete the unprofitable ones, making sure that after sufficient time, industries tended to be solely composed of maximizing firms. Before examining in more detail how this solution was itself framed after a statistical argument, let us briefly summarize our claims so far.

The institutional settings of his research around 1950 appear to have heavily influenced Alchian's approach to the issue of profit maximization. His activities at RAND had trained him to deal with wide discrepancies between classic assumptions in economic theory and "onsite" observations. He confronted uncertainty as a problem plaguing economic decisions with large error margins and threatening systems analysis with impotency. His 1950 article, written while the "criteria problem" was much discussed in the economics department at RAND, reflects Alchian's acknowledgment that uncertainty rendered both business leaders in industries and systems analysts at RAND incapable of reaching optimal solutions. He reckoned that in the estimation of the cost of airframes and of a firm's production costs alike, uncertainty was nullifying the prospects of a rational decision, if it meant predicting the maximum outcome. $\mathrm{He}$ could have ignored the problem and been satisfied with the assumption of

12. "Scholars of no less caliber than economist Kenneth Arrow concentrated on solving the problem" (Jardini 1996, 107). This would mean that Arrow's search for a utility function for the USSR, and his subsequent developing of his impossibility theorem, could be related to the vain search for a general evaluative criterion in systems analysis. Later, economists Charles E. Lindblom and James Buchanan would also spend some time at RAND on this problem, with no success (Jardini 1996, 108; Amadae 2003, 42, 145). 
certainty, but it would have been "assum[ing] the answer" (Alchian 1950, 213) to the problem at hand, when RAND's raison d'être was precisely to provide realistic answers informing operational decisions. Alternatively, Alchian could have chosen to handle uncertainty according to the popular definition of Frank Knight, who defined it as being out of reach of a statistical characterization. But Alchian was trained in statistics, and through the positive example of Fisher's redrawing of biological problems on statistical lines, he had gained confidence that it was the right tool with which to tame uncertainty. Indeed, what we want now to emphasize is that Alchian's article was not merely a recording of the difficulties implied by a rigorous statistical definition of uncertainty; it was also a statistical answer to this problem.

\section{A Reinterpretation of Alchian's Economic Natural Selection}

Alchian introduced his analysis with the hypothetical case of businessmen with no foresight, and insisted on the "fortuitous" circumstances that lead to the success or failure of firms to generate positive profits. If one expected the assumption of profit maximization to be rescued by Alchian's argument, one might have found his disregard of rationality and purposive behavior as ill oriented. Alchian was going even further than Hall and Hitch, who at least assumed some kind of rationality to describe the behavior of businessmen. Edith Penrose later noted that Alchian's orientations deprived economic analysis of what was then judged as its essential analytical power, namely, the study of the teleological behavior of the firm. But in giving up this perspective, Alchian reframed the problem as one analogous to statistical mechanics, and thereby benefited from some of its advances. If Alchian famously illustrated his argument with a biological analogy, he also developed a metaphor taken from French mathematician and statistician Emile Borel:

Suppose two million Parisians were paired off and set to tossing coins in a game of matching. Each pair plays until the winner on the first toss is again brought to equality with the other player. Assuming one toss per second for each eight-hour day, at the end of ten years there would still be, on the average, about a hundred-odd pairs; and if the players assign the game to their heirs, a dozen or so will still be playing at the end of a thousand years! The implications are obvious. Suppose that some business had been operating for one hundred years. 
Should one rule out luck and chance as the essence of the factors producing the long-term survival of the enterprise? (Alchian 1950, 215)

This analogy concatenated two sub-analogies. First, it implied that firms would simply be considered as molecular particles tossed repeatedly at a micro-level, the industry being the macro-state that such a molecular agitation created. The analogy allowed Alchian to consider firms as indeterminate particles, whose next move could not be predicted according to some maximum efficiency criterion, hence giving credence to Hall and Hitch's observations of the relatively sub-optimizing decision rules adopted by businessmen. Alchian was not giving up the prospect of a deterministic account of the representative firm's behavior. Indeed, statistical mechanics, which revolutionized physics in the late nineteenth century, had shown that it was possible to reconcile indeterminacy at the micro level and the deterministic, predictable mechanical properties of the system at the macro level. For instance in the theory of gas, a privileged domain of investigation in statistical mechanics, the existence of state parameters, such as temperature and pressure, for a system governed by the mechanical laws of classic physics, was interpreted as the result of the continuous averaging of random movements of gas molecules. This physical analogy could serve to acknowledge the relative free will of businessmen in a preserved marginal theory of the firm.

Under this view, it becomes unproblematic to acknowledge that businessmen's behavior does not conform to the iron rule of marginal pricing, and that they follow their own unpredictable policies, just like molecules in a gas moving in erratic and unpredictable ways. Indeed, in economics and physics alike, once statistically aggregated, the movements of those particles cause stable properties of the system to emerge. Then, studies revealing the idiosyncratic dispositions of businessmen cease to be a threat to the discovery of some general characteristics of a representative firmthey can even be considered as a confirmation of the normal functioning of the industry. Alchian was well aware of the benefits to be expected from this analogy:

It is not even necessary to suppose that each firm acts as if it possessed the conventional diagrams and knew the analytical principles employed by economists in deriving optimum and equilibrium conditions. The atoms and electrons do not know the laws of nature; the physicist does not impart to each atom a wilful scheme of action based on laws of conservation of energy, etc. The fact that an economist 
deals with human beings who have sense and ambitions does not automatically warrant imparting to these humans the great degree of foresight and motivations which the economist may require for his customary analysis as an outside observer or "oracle." The similarity between this argument and Gibbsian statistical mechanics, as well as biological evolution, is not mere coincidence. $(216 \mathrm{n} .12)^{13}$

The fact that the characteristics of the representative firm were of the type predicted by marginal analysis necessitated a second step in the exploration of those analogies. In Borel's thought experiment, selection is represented by the arbitrary rule stating that pairs get out of the game when equality between two players is reached. Alchian turned to the "economic natural selection" analogy to find a more elaborate notion of selection, which was made easier by the fact that the survival principle could be expressed both in statistical and biological terms. Darwinian natural selection had been reconceptualized by Fisher as a process of elimination of statistical variance in genetic fitness. A population of individuals heterogeneous from a fitness perspective would be driven, given sufficient time, to a state where the fittest organism will have diffused its characteristics to all the population. As no more variance among individuals' fitness is available to fuel it, evolution is brought to rest (Fisher's "Fundamental Theorem of Natural Selection"). When Alchian proposed that firms with less-than-zero profits would be driven out of competition, until a final equilibrium comprising only efficient firms would be reached, this mirrored the process described by Fisher's theorem. One should note that this second analogy is closely linked to, and in fact stems partly from, the first. As historians and philosophers of biology have noted, Fisher's natural selection entertained a strong relation to statistical mechanics:

Fisher ... sought to understand the dynamics of enormous arrays of genes in a population, rather than the casual pathways of single genes. He did this by importing into evolutionary biology models taken from statistical mechanics and thermodynamics. . . . Fisher, that is, tracked the trajectories of genes in the same probabilistic spirit in

13. See also the comment on a revised version of his article that Alchian addressed to Friedman, who refereed his paper for the Journal of Political Economy: "Fundamentally the paper seems to represent an attempt to integrate into economic analysis those methods used in other sciences (statistical mechanics and evolutionary adoption in biology) in an effort to explain and predict the apparent order in economic behavior despite uncertainty and diversity of motivation" (Alchian to Friedman, 10 November 1949, box 018, folder "19 Alchian," Milton Friedman Papers, Hoover Institution Archives). 
which Maxwell, Boltzmann, and Gibbs tracked arrays of gas molecules. (Depew and Weber 1995, 243-44)

In this twofold framework, an isolated system (be it a population of individuals, or a gas) is driven to a final state of rest. But while in statistical mechanics this state corresponds to the maximal disorganization of particles (as ruled by the Second Law of Thermodynamics), natural selection drives organisms toward maximum fitness and "higher organization in the organic world."14 In his reference to the statistical theory of natural selection, Alchian showed a similar trust in the convergence of the population toward a state of higher organization, meaning an industry tending to be populated by maximizing firms. Whereas in Fisher's evolutionary model the driving force was genetic fitness, in Alchian's, it was profits.

Firms, whose policies were closer to the prescription of marginal analysis, would triumph from those who adopt less-than-efficient policies, because on average and given sufficient time, their higher realized profits would make them expand, while others would shrink and eventually disappear. This model, in which evolution is driven by chance, was admittedly the "extreme" version of a generalized and more realistic analysis making room for purposive behaviors that Alchian studied in the last sections of his article.

For one, imitation of their successful competitors was a plausible rule of action for businessmen trying to cope with uncertainty. Trial-and-error was another adaptive behavior making firms likely to progress toward a (local) optimum. Even innovation could be expected from failed attempts to imitate a leading firm's best practice. These purposive behaviors seemed to contradict Alchian's earlier emphasis on chance as the engine of evolution toward a higher state of organization, and might signal that after all, the basic chance-model was just a provisional construction giving way to a different sort of evolutionary model. Alchian $(1950,216)$ anticipated this view and made it clear that

individual behavior according to some foresight and motivation does not necessarily imply a collective pattern of behavior that is different from the collective variety of actions associated with a random selection of actions. Where there is uncertainty, people's judgments and opinions,

14. Fisher 1930, 37, quoted in Hodge 1992, 252. Hodge documents the thesis that one should have a "two-tendency reading of Fisher's universe," reflecting the influence of Fisher's "two heroes" on his work: Ludwig Boltzmann, the founder of statistical mechanics, and Charles Darwin. 
even when based on the best available evidence, will differ; no one of them may be making his choice by tossing coins; yet the aggregate set of actions of the entire group of participants may be indistinguishable from a set of individual actions, each selected at random.

Was the result an evolutionary model? Certainly it was, as shown by the detailed economic natural selection analogy, featuring a rule of selection implying differential survival among firms. ${ }^{15}$ But it was also a mechanical analogy, as testified by the enfranchisement from uncertainty afforded by the statistical argument, and the reintroduction of a predetermined and well-specified outcome to the dynamics of intra-industry competition.

\section{Conclusion}

In view of the above we can reconsider the received view about the reintroduction of evolutionary economics around 1950. Since Thorstein Veblen or even Alfred Marshall, Darwinism had been transformed through its difficult encounter with Mendelism. The synthesis provided by Fisher, bringing together genetics and natural selection through a statistical reinterpretation of fitness, had made Darwinism dependent on population genetics models, defining the dynamics of evolution in reference to a closed system and to a final equilibrium to be reached. This should warn us from thinking of the reference to the "biological" or even "Darwinist" analogy in Alchian's article as the mark of a full-fledged evolutionary (non-deterministic in its outcome, historical in character) economic theory. The not-so-evolutionary conclusions of "economic natural selection" were amply demonstrated by its use in Friedman's (1953) essay on methodology. There, Friedman used Alchian's survival argument as a sister ship to the mechanical metaphor of the billiard player in support of maximization principles in economics, with evolutionary processes staying entirely out of the picture. ${ }^{16}$ It suggested that "natural selection" does not act as an unambiguous signal if one wants to judge whether the analogy is a mechanical one, or one of a different sort. As David Depew and Bruce

15. However, Alchian did not make it clear what kind of hereditary material possessed by the firm would insure the persistence of its behavior through time (an analogue to DNA and genes), an absence that was judged a serious weakness (Penrose 1952; Winter [1964] 1988; Hodgson 1994). Other problems included the overemphasis on purposive behavior as a factor of evolution, which bends the analogy toward Lamarckism rather than Darwinism.

16. Hence, it qualifies Neil Kay's (1995) insistence that Friedman's natural selection argument significantly departed from Alchian's original statement. 
Weber (1995) have convincingly argued, it might even be vain to search for a clear-cut distinction between a "Newtonian paradigm" and a Darwinian one, because these two paradigms, which are often presented as polar alternatives by social scientists, overlapped to some extent from the start (Depew and Weber reinterpret the Darwinian revolution as somewhat Newtonian in character.)

Nevertheless, it would be wrong to infer that modeling strategies remain unaffected by the call for an evolutionary framework. As later work has shown (e.g., Winter [1964] 1988, Nelson and Winter 1982, Hodgson 1994), an evolutionary program, even if having inevitable recourse to deterministic elements, lends itself more readily to the exploration of properties emerging from the interactions of basic units at a disaggregated level. But how much "evolution" there really is in such models will still lay very much in the eye of the beholder, as is well exemplified in the case of Alchian's classic paper, whose invocation of natural selection and statistical mechanics in entangled analogies triggered both the development of an evolutionary economic theory and a renewed confidence in physicsinspired marginal analysis.

\section{References}

Alchian, Armen A. 1949. Reliability of Progress Curves in Airframe Production. Santa Monica: RAND Corporation (RM-206-1, revised 3 February 1950).

- 1950. Uncertainty, Evolution, and Economic Theory. Journal of Political Economy 58.3:211-21.

- 1952. Economic Replacement Policy. Santa Monica: RAND Corporation (R-224, 12 April).

- 1953. Biological Analogies in the Theory of the Firm: Comment. American Economic Review 43.4:600-603.

1963. Reliability of Progress Curves in Airframe Production. Econometrica 31.4:679-93.

—. 1977. Economic Forces at Work: Selected Works by Armen A. Alchian. Indianapolis: Liberty Fund.

- 1982. General Discussion on Evolution and Human Behavior in the Conference on "Evolutionary Theory in Law and Economics." Research in Law and Economics 4:131-65.

- 2000. The Intellectual Portrait Series: A Conversation with Armen A. Alchian. Indianapolis: The Liberty Fund. [Audio file.]

_. [1996] 2006. Principles of Professional Advancement. In The Collected Works of Armen A. Alchian, edited by Daniel K. Benjamin. Indianapolis: Liberty Fund.

Amadae, S. M. 2003. Rationalizing Capitalist Democracy: The Cold War Origins of Rational Choice Liberalism. Chicago: University of Chicago Press. 
Benjamin, Daniel K., ed. 2006. The Collected Works of Armen A. Alchian. 2 vols. Indianapolis: Liberty Fund.

Boulding, Kenneth E. 1962. Conflict and Defense: A General Theory. New York: Harper.

Davis, Frederick B. 1948. Psychological Research in the AAF Aviation Psychology Program. Review of Educational Research 18.6:543-74.

Depew, David J., and Bruce H. Weber. 1995. Darwinism Evolving: Systems Dynamics and the Genealogy of Natural Selection. Cambridge: MIT Press.

Enke, Stephen. 1951. On Maximizing Profits: A Distinction between Chamberlin and Robinson. American Economic Review 41.4:566-78.

-1953. Biological Analogies in the Theory of the Firm: Comment. American Economic Review 43.4:603.

— ed. 1967. Defense Management. Englewood Cliffs: Prentice-Hall.

Fisher, Ronald A. 1930. The Genetical Theory of Natural Selection. Oxford: Oxford University Press.

_. [1925] 1932. Statistical Methods for Research Workers. 2nd ed. London: Oliver \& Boyd.

- 1935. The Design of Experiments. London: Oliver \& Boyd.

Friedman, Milton. 1953. Essays in Positive Economics. Chicago: University of Chicago Press.

Funkhouser, Richard L. 1941. Membership of the American Statistical Association on Its Hundredth Anniversary. Journal of the American Statistical Association 36.215:329-42.

Hall, Robert L., and Charles J. Hitch. 1939. Price Theory and Business Behaviour. Oxford Economic Papers 2 (May): 12-45.

Hirshleifer, Jack. 1977. Economics from a Biological Viewpoint. Journal of Law and Economics 20.1:1-52.

Hodge, M. J. S. 1992. Biology and Philosophy (Including Ideology): A Study of Fisher and Wright. In The Founders of Evolutionary Genetics: A Centenary Appraisal, edited by Sahotra Sarkar, 231-94. Dordrecht: Kluwer Academic Publishers.

Hodgson, Geoffrey M. 1993. Economics and Evolution: Bringing Life Back into Economics. Ann Arbor: University of Michigan Press.

- 1994. Optimisation and Evolution: Winter's Critique of Friedman Revisited. Cambridge Journal of Economics 18.4:413-30.

- 2005. Decomposition and Growth: Biological Metaphors in Economics from the 1880s to the 1980s. In The Evolutionary Foundations of Economics, edited by Kurt Dopfer, 105-48. Cambridge: Cambridge University Press.

Hounshell, David A. 2000. The Medium Is the Message, or How Context Matters: The RAND Corporation Builds an Economics of Innovation, 1946-1962. In Systems, Experts, and Computers, edited by Agatha C. Hughes and Thomas P. Hughes, 255-310. Cambridge: MIT Press.

Jardini, David R. 1996. Out of the Blue Yonder: The RAND Corporation's Diversification into Social Welfare Research, 1946-1968. PhD diss., Carnegie Mellon University.

Kaplan, Fred M. 1983. The Wizards of Armageddon. New York: Simon \& Schuster. 
Kay, Neil M. 1995. Alchian and "the Alchian thesis." Journal of Economic Methodology 2.2:281-86.

Kirat, Thierry. 1991. Pourquoi une théorie évolutionniste du changement technologique? Economie appliquée $44.3: 29-57$.

Lagueux, Maurice. 1998. Rationalité et sélection naturelle en économie. Philosophiques $25.2: 163-80$.

Lee, Frederic S. 1984. The Marginalist Controversy and the Demise of Full Cost Pricing. Journal of Economic Issues 18.4:1107-32.

Leonard, Robert J. 1991. War as a "Simple Economic Problem": The Rise of an Economics of Defense. In Economics and National Security, edited by Craufurd Goodwin, 32-54.

Lester, Richard A. 1946. Shortcomings of Marginal Analysis for Wage-Unemployment Problems. American Economic Review 36.1:63-82.

Levallois, Clément. 2008. Economie et biologie aux Etats-Unis (1950-1982). PhD diss., Université de Lyon.

Machlup, Fritz. 1946. Marginal Analysis and Empirical Research. American Economic Review 36.4:519-54.

Mirowski, Philip. 1999. Cyborg Agonistes: Economics Meets Operations Research in Mid-Century. Social Studies of Science 29.5:685-718.

- 2002. Machine Dreams: Economics Becomes a Cyborg Science. Cambridge: Cambridge University Press.

Mongin, Philippe. 1986. La controverse sur l'entreprise (1940-1950) et la formation de l' "irréalisme méthodologique." Economies et sociétés 20.5:95-151.

- 1992. The Full-Cost Controversy of the 1940s and 1950s: A Methodological Assessment. HOPE 24.2:311-56.

Nelson, Richard R., and Sidney G. Winter. 1982. An Evolutionary Theory of Economic Change. Cambridge: The Belknap Press of Harvard University Press.

Oklin, Ingram. 1991. A Conversation with W. Allen Wallis. Statistical Science 6.2:121-40.

Penrose, Edith T. 1952. Biological Analogies in the Theory of the Firm. American Economic Review 42.5:804-19.

- 1953. Biological Analogies in the Theory of the Firm: Rejoinder. American Economic Review 43.4:603-9.

Rice, Stuart A., and Morris Green. 1929. Interlocking Memberships of Social Science Societies. Journal of the American Statistical Association 24.167:303-6.

Salsburg, David S. 2001. The Lady Tasting Tea: How Statistics Revolutionized Science in the Twentieth Century. New York: Owl Books.

Smith, Walter L. 1978. Harold Hotelling, 1895-1973. Annals of Statistics 6.6:1173-83.

Solal, Philippe. 1999. Métaphores, analogies, et comportements: La position d'Edith T. Penrose. Economies et sociétés 29.8:123-42.

Vromen, Jack J. 1995. Economic Evolution: An Enquiry into the Foundations of New Institutional Economics. London: Routledge.

Winter, Sidney G. [1964] 1988. Economic "Natural Selection" and the Theory of the Firm. In Behavioral Economics, edited by Peter E. Earl, 225-72. Aldershot: Edward Elgar. 


\section{Publications in the Report Series Research* in Management}

\section{ERIM Research Program: “Marketing"}

2008

Experts' Stated Behavior

Youssef Boulaksil and Philip Hans Franses

ERS-2008-001-MKT

http://hdl.handle.net/1765/10900

The Value of Analogical Reasoning for the Design of Creative Sales Promotion Campaigns: A Case-Based Reasoning Approach

Niek A.P. Althuizen and Berend Wierenga

ERS-2008-006-MKT

http://hdl.handle.net/1765/11289

Shopping Context and Consumers' Mental Representation of Complex Shopping Trip Decision Problems

Benedict G.C. Dellaert, Theo A. Arentze and Harry J.P. Timmermans

ERS-2008-016-MKT

http://hdl.handle.net/1765/11812

Modeling the Effectiveness of Hourly Direct-Response Radio Commercials

Meltem Kiygi Calli, Marcel Weverbergh and Philip Hans Franses

ERS-2008-019-MKT

http://hdl.handle.net/1765/12242

Choosing Attribute Weights for Item Dissimilarity using Clikstream Data with an Application to a Product Catalog Map Martijn Kagie, Michiel van Wezel and Patrick J.F. Groenen

ERS-2008-024-MKT

http://hdl.handle.net/1765/12243

The Effect of Superstar Software on Hardware Sales in System Markets

Jeroen L.G. Binken and Stefan Stremersch

ERS-2008-025-MKT

http://hdl.handle.net/1765/12339

Sales Growth of New Pharmaceuticals Across the Globe: The Role of Regulatory Regimes

Stefan Stremersch and Aurélie Lemmens

ERS-2008-026-MKT

http://hdl.handle.net/1765/12340

When Intelligence is (Dys)Functional for Achieving Sales Performance

Willem J. Verbeke, Frank D. Belschak, Arnold B. Bakker, and Bart Dietz

ERS-2008-034-MKT

http://hdl.handle.net/1765/12633

Path Dependencies and the Long-term Effects of Routinized Marketing Decisions

Paul Farris, Willem J. Verbeke, Peter Dickson and Erjen van Nierop

ERS-2008-035-MKT

http://hdl.handle.net/1765/12634

Does Irritation Induced by Charitable Direct Mailings Reduce Donations?

Merel van Diepen, Bas Donkers and Philip Hans Franses

ERS-2008-036-MKT

http://hdl.handle.net/1765/12704 
Brain Mechanisms of Persuasion: How "Expert Power" Modulates Memory and Attitudes

Vasily Klucharev, Ale Smidts and Guillén Fernández

ERS-2008-038-MKT

http://hdl.handle.net/1765/12784

Moderating Factors of Immediate, Dynamic, and Long-run Cross-Price Effects

Csilla Horváth and Dennis Fok

ERS-2008-042-MKT

http://hdl.handle.net/1765/12901

Why, How and When Do Prices Land? Evidence from the Videogame Industry

Carlos Hernandez-Mireles, Dennis Fok and Philip Hans Franses

ERS-2008-044-MKT

http://hdl.handle.net/1765/12900

Situation-Based Shifts in Consumer Web Site Benefit Salience: The Joint Role of Affect and Cognition

Sonja Wendel and Benedict G.C. Dellaert

ERS-2008-050-MKT

http://hdl.handle.net/1765/13179

Including Item Characteristics in the Probabilistic Latent Semantic Analysis Model for Collaborative Filtering

Martijn Kagie, Matthijs van der Loos and Michiel van Wezel

ERS-2008-053-MKT

http://hdl.handle.net/1765/13180

Cross-National Logo Evaluation Analysis: An Individual Level Approach

Ralf van der Lans, Joseph A. Cote, Catherine A. Cole, Siew Meng Leong, Ale Smidts, Pamela W. Henderson, Christian

Bluemelhuber, Paul A. Bottomley, John R. Doyle, Alexander Fedorikhin, M. Janakiraman, B. Ramaseshan,

and Bernd $H$. Schmitt

ERS-2008-055-MKT

http://hdl.handle.net/1765/13181

Sales and Sincerity: The Role of Relational Framing in Word-of-Mouth Marketing

Mirjam A. Tuk, Peeter W.J. Verlegh, Ale Smidts and Daniel H.J. Wigboldus

ERS-2008-056-MKT

http://hdl.handle.net/1765/13183

Interpersonal Relationships Moderate the Effect of Faces on Person Judgments

Mirjam A. Tuk, Peeter W.J. Verlegh, Ale Smidts and Daniel H.J. Wigboldus

ERS-2008-057-MKT

http://hdl.handle.net/1765/13185

Evaluative Conditioning 2.0: Referential versus Intrinsic Learning of Affective Value

Steven Sweldens, Stijn M.J. van Osselaer, and Chris Janiszewski

ERS-2008-062-MKT

http://hdl.handle.net/1765/13612

Gender Identity Salience and Perceived Vulnerability to Breast Cancer

Steven Sweldens, Stefano Puntoni, and Nader Tavassoli

ERS-2008-063-MKT

http://hdl.handle.net/1765/13613

The Emotional Information Processing System is Risk Averse: Ego-Depletion and Investment Behavior

Bart De Langhe, Steven Sweldens, Stijn M.J. van Osselaer, and Mirjam Tuk

ERS-2008-064-MKT

http://hdl.handle.net/1765/13614 
The Moderating Roles of Relationship Quality and Dependency in Retailers' New Product Adoption Decisions Yvonne M. van Everdingen, Laurens M. Sloot, and Peter C. Verhoef

ERS-2008-065-MKT

http://hdl.handle.net/1765/13615

Modeling Global Spill-Over of New Product Takeoff

Yvonne M. van Everdingen, Dennis Fok, Stefan Stremersch

ERS-2008-067-MKT

http://hdl.handle.net/1765/13616

Measuring Productivity Change without Neoclassical Assumptions: A Conceptual Analysis

Bert M. Balk

ERS-2008-077-MKT

http://hdl.handle.net/1765/13876

One Analogy Can Hide Another: Physics and Biology in Alchian's "Economic Natural Selection" Clément Levallois

ERS-2008-083-MKT

http://hdl.handle.net/1765/14278

* A complete overview of the ERIM Report Series Research in Management: https://ep.eur.nl/handle/1765/1

ERIM Research Programs:

LIS Business Processes, Logistics and Information Systems

ORG Organizing for Performance

MKT Marketing

F\&A Finance and Accounting

STR Strategy and Entrepreneurship 